\title{
Factors impact on insufficient nutrition and effects of timely adequate nutrition support on patient outcomes in adult intensive care patients
}

\author{
Y Savran ${ }^{1 *}$, M Limon², ME Tokur', B Comert ${ }^{1}$ \\ From ESICM LIVES 2015 \\ Berlin, Germany. 3-7 October 2015
}

\section{Introduction}

Most of the studies comparing effects of enteral and parenteral nutrition on morbidity and mortality have been performed on surgery patient groups or in mixed intensive care unit patients. Numbers of studies performed in medical intensive care units are limited and they all include few number of patients.

\section{Objectives}

In the present study we aimed to analyze association of adequacy of nutrition support with infectious complications, length of stay in intensive care unit and hospital, and mortality in medical intensive care unit patients and causes of insufficient nutrition in patients who are not met target daily caloric intake.

\section{Methods}

Data of patients who were hospitalized in medical ICU between January 2012 and December 2013 were reviewed retrospectively. Patients older than 18 years of age and who had been dependent to mechanical ventilation for at least 3 days were included. 220 patients were determined after retrospective review of patient files with laboratory and imaging results.

\section{Results}

133 male and 87 female patients were included. 151 patients reached the target caloric intake.Mean target calorie was $1579 \mathrm{kcal} / \mathrm{d}$ in the adequate caloric intake group, and $1739 \mathrm{kcal} / \mathrm{d}$ in insufficient caloric intake group $(\mathrm{p}<0.001)$. The number of comorbidities in both groups were similar $(1.91 \pm 1.07 / 1.87 \pm 1.00 ; \mathrm{p}>0.05)$.According

Dokuz Eylul University Faculty of Medicine, Internal Medicine Intensive Care Unit, Izmir, Turkey

Full list of author information is available at the end of the article to logistic regression analysis parenteral nutrition and lymphoma were found to be major independent risk factors for insufficient calorie intake. The most common cause for cessation of nutrition was detection of a residual. Nosocomial infection frequency in adequate and insufficient caloric intake groups were similar, respectively. Enteral nutrition was the most effective feeding way in adequate caloric intake group $(\mathrm{p}<0.002)$. Parenteral nutrition and immunosuppressive treatment were major independent risk factors for mortality based on logistic regression analysis.Mortality of patients in adequate and insufficient caloric intake groups was $53 \%$ and $76 \%$, respectively $(\mathrm{p}<0.002)$.

\section{Conclusions}

Enteral nutrition in critical care patients is safe and effective. Patients who were fed enterally were more associated with reaching the target caloric intake.It is far more difficult to reach target caloric intake by parenteral nutrition and it is associated with an increase in mortality.

More effort should be sought for the continuity of enteral nutrition.Adequate amounts of nutrition significantly decreases mortality.

\footnotetext{
Authors' details

${ }^{1}$ Dokuz Eylul University Faculty of Medicine, Internal Medicine Intensive Care Unit, Izmir, Turkey. ${ }^{2}$ Dokuz Eylul University Faculty of Medicine, Internal Medicine, Izmir, Turkey.

Published: 1 October 2015

\section{References}

1. Heyland DK, Dhaliwal R, Drover JW, Gramlich L, Dodek P, Canadian Critical Care Clinical Practice Guidelines Committee: Canadian clinical practice guidelines for nutrition support in mechanically ventilated, critically ill adult patients. JPEN J Parenter Enteral Nutr 2003, 27(5):355-373.
}

(c) 2015 Savran et al.; This is an Open Access article distributed under the terms of the Creative Commons Attribution License (http:// creativecommons.org/licenses/by/4.0), which permits unrestricted use, distribution, and reproduction in any medium, provided the original work is properly cited. 
2. Zaloga GP: Parenteral nutrition in adult inpatients with functioning gastrointestinal tracts: assessment of outcomes. Lancet 2006, 367(9516):1101-1111.

doi:10.1186/2197-425X-3-S1-A585

Cite this article as: Savran et al:: Factors impact on insufficient nutrition and effects of timely adequate nutrition support on patient outcomes in adult intensive care patients. Intensive Care Medicine Experimental 2015 3(Suppl 1):A585.

\section{Submit your manuscript to a SpringerOpen ${ }^{\circ}$ journal and benefit from:}

- Convenient online submission

- Rigorous peer review

- Immediate publication on acceptance

- Open access: articles freely available online

- High visibility within the field

- Retaining the copyright to your article

Submit your next manuscript at $\gg$ springeropen.com 